\title{
The Factor Influencing Brand Loyalty in Fashion Industry among Generation Y in Malaysia
}

\author{
Dilashenyi Devi Selvarajah $^{1}$ \\ ${ }^{1}$ Faculty of Business, Accountancy and Management, SEGi University, Malaysia \\ Correspondence: Dilashenyi Devi Selvarajah, Faculty of Business, Accountancy and Management, SEGi \\ University, Malaysia. E-mail: dilashenyiselvarajah@gmail.com
}

Received: November 29, 2017

doi:10.5539/ijbm.v13n4p201

\begin{abstract}
Brand loyalty has place at the middle of the both marketing theory and the practice since it is the origin of the revenue. The revenue usually get it from the customer feedback, price premiums, increased in sales, higher balance, and the cut operating costs. The reason or gap to study this research is to analyze the factors that influence brand loyalty to fashion industry. The finding of this study not only improving the understanding of the different factors in increase the brand loyalty for the brand, but also help in market segment and formulate appropriate customer retention policies that are more cost-effective than others. The main objective of this research is to investigate the factors that influence brand loyalty in fashion industry in Malaysia. The purpose existence, it will provide certain procedures or else guidelines to the researcher to resolve the problematic that get up in the issue deliberated. These results might be a proof for future researchers or the surveyor.
\end{abstract}

Keywords: buying behavior, brand experience, customers satisfaction, switching cost

\section{Introduction}

The youngster (Generation Y) is the huge market for the organization to target, Gen $\mathrm{Y}$ have the ability to purchase fashion items and they able to keep in touch or follow the fashion. Since fashion is the industry that keep innovative and changing industry, especially for fashion in women sector. (Hill \& Lee, 2012) If the brand loyalty for an organization in fashion industry is low, they might face many impact to them. Such as their customer may go to competitor's side, unbalance of income, brand image and satisfaction by the customer is low. For example, H\&M fashion company and Forever 21 Fashion Company their customer switching cost is low. So their customer may easily go to the competitor's side, especially for ladies customer.

According to Son, K. previously there are many researchers have done the research on customer brand loyalty. The mature market have considering the most of the consumers are general consumer and no specific target segment. (Son, 2010) This shows that, the brand loyalty of generation Y have become the new area to research this is because most of them are the one who that keep update in current trend. This could be the threat for the organization since generation $\mathrm{Y}$ is keep changes their fashion style rapidly and the consumers are no longer loyal to only one brand.

There are numerous researches on the brand loyalty being supported in developed countries such as Taiwan, US and UK. The area of brand loyalty are extensive and its potential factors are likely already been investigated by others. However, this study is to concerning the effect of important factors on brand loyalty in fashion industry among generation $\mathrm{Y}$ in Malaysia. The result from this study can contribute to an organization better understanding on generation Y market and help to improve the brand loyalty in fashion industry. Based on the academic research this study contains dependent variables and independent variables. Which every single variable will be more clarified to confirm the important with each other.

\section{Research Objectives}

1. To investigate the consumer behavior of generation $\mathrm{Y}$ on brand loyalty for fashion industry.

2. To investigate the switching costs in fashion industry.

3. To investigate the brand experience that affect brand loyalty in fashion industry.

4. To investigate the customer satisfaction toward brand loyalty in fashion industry. 


\section{Literature Review}

\subsection{Brand Loyalty}

In the business world, brand loyalty is very importance and also always highly recognized. Brand loyalty has considered as the one of the key constructs on most conceptualizations of the consumer brand equity. (Veloutsou, Christodoulides, \& de Chernatony, 2013)

"As the brand's percentage of loyal customers goes up, market share increases and the brand becomes more profitable (Kotler \& Keller, 2006)."

According to the statement above, brand loyalty can be defined as is an outcome of the consumer behavior and which influence by a person preferences. In other words, brand loyalty is the consumer that will repeat purchases from their preferred brands no matter how the competitors differ the price. They will not seek to the substitute brands and the consumer will perceive that the brand that they prefer is more superior compare to other brands. The growing of number of customers could lead to the word of mouth and greater resistance in between the loyal customer and the price sensitive for them will lower once them loyal to the brand. Brand loyalty also can be defined as the positive feelings of consumer towards the brand and the intense dedication to keep repeated purchase the same product or services. The loyalty consists of both attitudinal and the behavioral component. Attitudinal loyalty which is the willingness of consumer to purchase at a higher price and overcome the obstacles to purchase. (Liu, Li, Mizerski, \& Soh, 2012) The behavioral loyalty which is the actual action of repeating purchases. For example, the consumer may have display behavioral loyalty by purchasing the Apple IPhone when there are few alternatives are available in the market but the attitudinal loyalty will mean they will not buy an alternative brand. Fornerino and D'Hauteville have used the behavioral learning theories to analyze how the incentives may affect brand loyalty. (Fornerino \& D'Hauteville, 2010) The journal stated that if the price incentives are more attractive than the benefits of a brand provide, then the consumers will use the prices incentives causing the brand loyalty to be affected. The brand loyalty may increase if other advantages of a brand is more outstanding than the price incentives.

\subsection{Fashion Industry}

Fashion can be define as is a concept of more than one interpretations and applied in the different contexts. (Barnard, 2002) Fashion also known as a popular trend that in the style of dress. The words that are used to relate to fashion which is style, clothing, accessories and dress. Usually that are designed by the famous fashion designer. Fashion can be associated with change and define by the succession of the short duration trends. The changes are always been associated by the economic, social, political transformations, which end in the development of new products. (Arnold R. , 2009)

In previously, fashion apparel organization used to forecast the wants and needs of consumers and they creates the demands by launching of seasonal trends. This make the fashion industry became a high competitive market as the organization keep offering the lower price and with the better quality to try to against and competes other competitors. However this method is no longer to use in today world. Currently the fashion industry are using the changing of demands and behavior from the consumer method. Which create the trend of fashion that let consumer keep follow the latest fashion. Previously was the organization predict what consumers needs and wants, but now is consumer follow the organization that designed and they do not directly predict what they wants. (Christopher, Lowson, \& Peck, 2004)

\subsection{Generation $Y$}

According to Valentine and Powers that a generation can be defined as an identifiable group of people that shares age, location, and significant life events at the critical development stage. (Valentine \& Powers, 2013) The generation Y which is born between years 1981 to 1999 based on the USA standard. (Richard, 2011) There is other term that used to call generation $\mathrm{Y}$ which is Millennial. The generation $\mathrm{Y}$ consumers today are playing an important role in segment market, because of their large size and their current significant amount of spending power, also the potential for huge amount of spending in the future time. According to Statistic Government Malaysia the population of generation Y in Malaysia is 38.1\% over the total population Malaysia in 2015 . (pqi.stats.gov.my, 2015) Which is the largest group in Malaysia. Generation Y is the most potential market for the organization to target on. Since generation Y people are young and have the financial power, the organization if can reaching them in the early stage and build a good relationship with them could be the most profitable relationship in the future. Because the loyalty or the life time value of generation $\mathrm{Y}$ consumer is much longer compare to generation $\mathrm{X}$ and they much know how to enjoy their life better than generation X. (Foscht, Schloffer, III, \& Chia, 2010). That is not easy for an organization to capture the loyal from Generation Y consumers, 
because they are in a large size and their life style is different from generation X. They prefer to try new things which could lead the switching brand increase. The best way is to create the good relationship with them to make them as a loyal customers that keep repeating buying the same brand products. (Fountain \& Lamb, 2011).

\subsection{Consumer Behavior}

According to the researcher Patti Williams, he explain that the behavior is explained by the external events and that things that organisms do. Which including the actions, feelings, and thoughts that can be regarded as behavior. (Williams, 2014) Besides that, Darren Dahl has defines that human as self-interested and rational, and making decisions based upon the capacity to expand utility while consuming the slightest exertion. (Dahl, 2013) While in the point of view of Arnold that psychodynamic approach as the behavior that subject to biological influence which through drives and instinctive forces. Which act outside of the conscious thought while Freudian identified three factors of approach as Id (Is the warehouse of primitive needs for which individual seek to immediate satisfaction), ego (Is an individual conscious control that to balances the demands of both Id and Superego) and superego (Is an individual internal expression of society moral and the ethical codes of the conduct). (Arnold J. , 1991)

Also, consumer behavior can be defined as is the study of the processes involved when a groups or an individual is select, use or purchase of the products and service, ideas or experiences to satisfy the needs and desires. (Solomon, 2006) Another two authors of Consumer Behavior book $9^{\text {th }}$ edition Schiffman and Kanuk have defines the consumer behavior in quite a similar meaning with Solomon. Which defined as the behavior that consumer the display in searching for the using, purchasing, disposing and evaluating of the products and service that they expect will satisfy the consumer's needs. (Schiffman L. G., 2007). Based on the above discussion, it can be seen that there is a relationship between consumer behavior and brand loyalty. Thus it is included in this research conceptual framework.

\subsection{Customer Satisfaction}

In the customer satisfaction can be the internal or external satisfaction. Internal satisfaction which is the organization to satisfy it employees. External satisfaction which is the organization have to let their customers satisfy their product or services. The researcher Gilbert that he defines satisfaction as a whole consumer that response in which consumer show on their pleasure level. While the consumer satisfaction can be defined as is the overall level of attainment of an expectation from customer. (Gilbert E. Chodzaza, 2013) Besides that, the author Oliver has defined that the customer satisfaction as the well fed meeting of consumer expectation of the products and services. In order words, if the expected performance have matches the customer's expectation, which mean they are satisfied. But if it doesn't match the customer expectation which mean they are dissatisfied. (Oliver, 1997)

The researcher Youl said that if a customer is satisfied they would like to purchases the same brand in the future as well as if the brand satisfaction has a positive influence on the brand loyalty. If the customers has feel please and satisfaction after they use or try the product, it will create a long-term relationship between the organization and customer, and they will repeat purchase the products with you. For example, the skin care product if the customer have try the brand and satisfy with it the particular customer will keep repeat using the same brand products. (Youl, 2010). Based on the above discussion, it can be seen that there is a potential relationship between customer satisfaction and brand loyalty. Thus it is included in this research conceptual framework.

\subsection{Switching Cost}

There are many definition about switching cost that define by various researchers. The switching cost can be describes as the way that companies can take competitive advantages by making it more costly and hard for a customer to switch to their competitors. (Brush, Dangol, \& O'Brien, 2012) Also, switching costs can also define as the conceptualized as the customer perception towards magnitude of more costs to finish the current relationship and guarantee the alternative one such as the perceived costs which to prevent the customer switch to the competitors offer. (Yanamandram \& White, 2006) In other words, the researchers like Matos, Henrique, \& Rosa in their research they defines switching costs are the customer perception which concerning time, effort and money associated to change in the service providers, or the direct costs that consumers associated to switching other alternative brands. There are three types of switching cost (1) Procedural costs - this costs which is the time costs, effort spent, and consist of economicn risk, set up costs, and evaluation costs, (2) Financial costs the financial costs consists of the loss in financial costs and the benefits as well and (3) Relational costs - this which involve discomfort of psychological or emotional due to the identity loss. As the three costs above and the satisfaction program which contribute to increase the customers retention rate. (Matos, Henrique, \& Rosa, 2009) 
Another researchers like Park, Park, \& Lee they have argue that the customer switching costs have play an important role in the firm ability to retain the customers and achieve the competitive advantage. If the organization can create the barrier of diffcult and costly for a customers to switch to other competitors, the organization can have comeptitive advantage. (Park, Park, \& Lee, 2014) Based on the Haj-Salem research, there are many companies spends lot of effort to creating the switching costs in order to enhance customer retention and get competitive advantages. (Haj-Salem, 2014). Based on the above discussion, it can be seen that there is a potential relationship between switching costs and brand loyalty. Thus it is included in this research conceptual framework.

\subsection{Brand Experience}

There are many previous researchers that define about brand experience. One of the researcher Hae Jung Kim has defines the brand experience which consists of product experience (It occurs when the consumers interact with a product.), service experience (It occur when the consumer intereact to a store persoonel variables and atmospheric.), and the consumption experience which happen to multidimensional constitution. (Kim, 2012) . Besides that, the researcher Bernd Schmitt has done the his research and he defines that the word 'experience' which can be defined as the term means to ongoing feelings, perceptions, direct observations, and also refers to the past, the experience collected from past, and referring to the knowledge. In addition, the brand experiences which refer to the interaction between consumers and the brand product, either purchased the product or before puchase the product.(Schmitt, 2013).

Martin Zwilling the researcher he said that the customer experience is the brand. Customer will always remember the experience rather than your brand logo, if the experience that given by the brand could satisfy the customer they will loyal to the brand. It also can be link to the word-of-mouth, once they have experience the brand and having the positive experience they will introduce the brand to their friends and family. (Zwilling, 2013).The brand experience can be describe as is the sensory dimensions of the brand experience. Which target on the sense of smell, touch, vision and taste. The dimension can be separate into fours which the affective dimension is refers to the consumer emotion and their inner feeling to the brand. The cognitive dimension which have involves a consumer creative thinking way and the way of the reproducing the things in to a different manner. Next, the social dimension which refers to the experiences in pursuit to moving individualism to collectivism by including the people, a groups or a society. (Zarantonello \& Schmitt, 2010)

\section{Theories}

Based on the research, there are some theory can be use to determine the factors that are explaining the brand loyalty in the fashion industry. From the theories that have been stated some of the factors that need to take in consideration due to those factors which will give aserious impact on the brand loyalty in the fashion industry. According to the Sheth and Park, they have stated that the brand loyalty is the hypothetical contruct which is a variable that cannot be observe directly. The Multidimensional construct which is the determined by few distinct psychological process. (Park J. N., 1974) The theories of brand loyalty can be define as a positively biased tendency that has three distinct dimensions. The first dimension which is emotive tendency which toward the brand where affective, respect, and fear. The compliance tendency which is the systematically and shown more in the favour of the brand than other brands in the market place that is related. (Katz, 1960)

The second dimension which is evaluative tendency that toward the brand. It is the evaluation of the brand on a set of the requirement which is related to convey out the brand utility to the customers. For example, the brand of Mercedes car as an automobile that give message to the consumer on the safety and durability. Furthurmore, Katz has suggest that the instrumental and utilitarian attudes as well as the perceived instrumentality component of the Rosenberg model is the evaluative tendency. (Rosenberg, 1956). The third dimension which is behavioural tendency toward the brand. In this tendecy which is the responses toward the brand with the respect to its acquisition, purchase and consumption activities. The behavioural dimension have include all the action from the buyer of searching, buyingm and selecting the brand physically, and paying for the product or service and using it. In the summary of it, mean that the time and the action study of the consumer as he behaves toward the brand in a way. As conlude that, the behavoural tendency is come from the experiences of the purchasing and consuming from the brand. (Park J. N., 1974) 


\section{Research Framework}

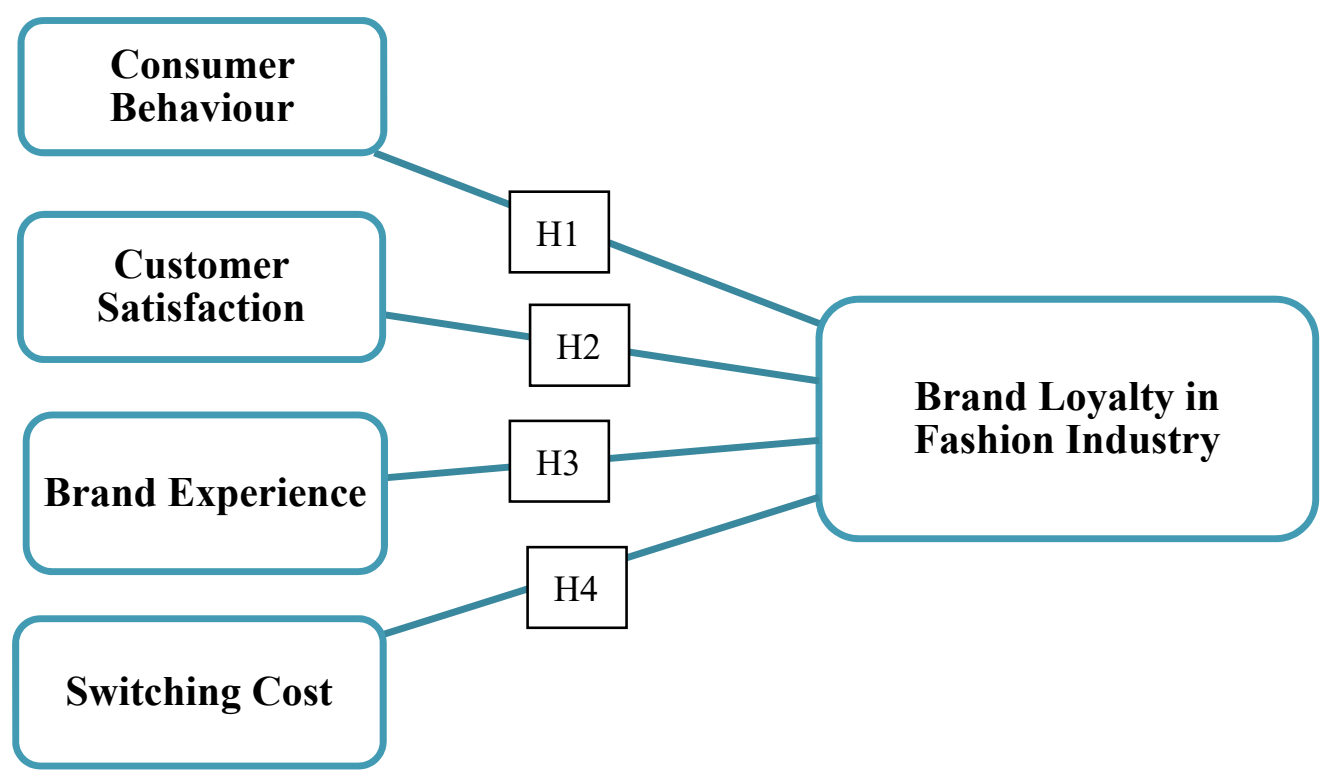

The reseach framwork as illustrated in the Figure above decribe that the independence variables and the dependence variables in this research. The dependent virables in the framework above is the brand loyalty in fashion industry. The independent varaibles in the framwork above have including consumer buying behavior, customer satisfaction, brand experience and switching cost. This research is to study the factors that affect brand loyalty in fashion industry. The proposed framwork illustrated above have shows that consumer buying behavior, customer satisfaction, brand experience and switching cost entails a forthright relationship with the brand loyalty in fashion industry.

\section{Results and Discussion}

Dependent Variable can be define as the response that is to measured after making changes to the independent variable. The independent variable can be define as is the variable that change in order to determine he or she dependent variable. (McLeod, 2015) The factors that influence brand loyalty of the fashion industry are the consumer buying behavior, brand experience, customer satisfaction, and switching costs. The sample items are based on the previous researches and some had been modify based on the origins. The questionnaire is using the likert scale to measure the response from the survey research. In the questionnaire, the respondent is require to rate the various factors influencing the brand loyalty of Generation Y in Malaysia.

Pilot Test which is a small scale of study, which the results are only preliminary and proposed only to support in the design of a following study. This test is conducted before attempt for the larger scale of survey. The main purpose of the pilot test which is to test the reliability and the validity as well as recognize the errors of the questions in the questionnaire that designed. The pilot test will conclude with the results of Cronbach's Alpha which is used to examine the reliability of the test. The total number distributed for the purpose of pilot test which is 30 respondents. This test was conducted by using SPPS version 20.

The data testing is to help in meeting the multivariate assumptions before the multiple regressions possibly will be tested. There are four forms of data testing assumptions such as normality, linearity, homogeneity, and also the multicollinearity. Normality test which is use the observe the degree of the distribution data matches to the normal distribution. The shape of it will be roughly like a bell-shaped curve. Besides that, linearity is that the research variables which are related to each other in a linear manner and is a straight line scatterplot. The pearson correlation coefficients which assess the degree of linear relationship between the two variables. Correlation is the descriptive statistics to understand and possibly one of the most methods widely. The word correlation means "co-relate" and refers to the measurement of a relationship between two or more variables. A correlation coefficient is normally range between -1.0 and +1.0 . Furthermore, the homoscedasticity assumption is the computable dependent variable which have the equal levels of the variability across the independent variable. (Hair, Anderson, Tatham, \& Black, 1998) Lastly, the multicollinearity is the several independent variables which in the multiple regression models are closely interrelated to another. The problem happened when the tolerance is 
below 0.2 and the variance inflation factor is higher than 4.0.

Table 1. Reliability Statistics

\begin{tabular}{ll}
\hline Cronbach's Alpha & N of Items \\
\hline .776 & 30 \\
\hline
\end{tabular}

Based on the results shown in the table above, the cronbach's alpha is 0.776 . Which is more than 0.70 , this mean that the pilot test is reliable and can be used for further research on more respondents to achieve the better data.

\subsection{Correlation Test}

Table 2. Correlations

\begin{tabular}{|c|c|c|c|c|c|c|}
\hline & & brand loyalty & consumer behavior & $\begin{array}{l}\text { Customer } \\
\text { satisfaction }\end{array}$ & $\begin{array}{l}\text { brand } \\
\text { experience }\end{array}$ & switching cost \\
\hline \multirow{3}{*}{ brand loyalty } & Pearson Correlation & 1 & $.508^{* *}$ & $.288^{* *}$ & .138 & .098 \\
\hline & Sig. (2-tailed) & & .000 & .000 & .051 & .167 \\
\hline & $\mathrm{N}$ & 200 & 200 & 200 & 200 & 200 \\
\hline \multirow{3}{*}{ consumer behavior } & Pearson Correlation & $.508^{* *}$ & 1 & $.291^{* *}$ & .114 & .096 \\
\hline & Sig. (2-tailed) & .000 & & .000 & .107 & .178 \\
\hline & $\mathrm{N}$ & 200 & 200 & 200 & 200 & 200 \\
\hline \multirow{3}{*}{ Customer satisfaction } & Pearson Correlation & $.288^{* *}$ & $.291^{* *}$ & 1 & $.152^{*}$ & .132 \\
\hline & Sig. (2-tailed) & .000 & .000 & & .032 & .062 \\
\hline & $\mathrm{N}$ & 200 & 200 & 200 & 200 & 200 \\
\hline \multirow{3}{*}{ brand experience } & Pearson Correlation & .138 & .114 & $.152^{*}$ & 1 & $.389^{* *}$ \\
\hline & Sig. (2-tailed) & .051 & .107 & .032 & & .000 \\
\hline & $\mathrm{N}$ & 200 & 200 & 200 & 200 & 200 \\
\hline \multirow{3}{*}{ switching cost } & Pearson Correlation & .098 & .096 & .132 & $.389^{* *}$ & 1 \\
\hline & Sig. (2-tailed) & .167 & .178 & .062 & .000 & \\
\hline & $\mathrm{N}$ & 200 & 200 & 200 & 200 & 200 \\
\hline
\end{tabular}

**. Correlation is significant at the 0.01 level (2-tailed).

*. Correlation is significant at the 0.05 level (2-tailed).

Pearson's correlation coefficient is an analysis that to measures the relationship between two variables. If the variable has an impact on another variable, then it is said to have a correlation in between these two variables (University of the West of England, 2015). These two variables are the dependent and independent variables, where the independent variables are used as an indicator, whilst the dependent variables are the reflection/change that might occur (Achelis, 2015). In this research, the correlation analyses are analysed by the SPSS versions 20 software with the data of collection from 200 respondents. The correlation coefficient in SPSS software are normally ranged between \pm 1.0 with a coefficient of +1.0 meaning "perfect positive correlation", whilst -1.0 meaning "perfect negative correlation". For a perfect positive correlation mean if any changes in independent variables will have a direct impact on the dependent variables. On the other side, a perfect negative correlation is mean that if any change in the independent variables will not have any direct impact on the dependent variables. Hence no change will occur. Based on the correlation that was analyzed by the SPSS software, it is obvious that amongst the four independent. There are all positive correlation with the dependent variable (Brand loyalty), whereas the consumer behavior have the highest correlation with the dependent variable (Brand loyalty).

\subsection{Model Summary}

Table 3. Model summary ${ }^{\mathrm{b}}$

\begin{tabular}{llllll}
\hline Model & $\mathrm{R}$ & R Square & Adjusted R Square & $\begin{array}{l}\text { Std. Error of theDurbin-Watson } \\
\text { Estimate }\end{array}$ \\
\hline 1 & $.533^{\mathrm{a}}$ & .284 & .269 & .40613 & 1.610 \\
\hline
\end{tabular}

a. Predictors: (Constant), switching cost, consumer behavior, Customer satisfaction, brand experience

b. Dependent Variable: brand loyalty 
This research has $28.4 \%$ of total variation of dependent variables, which can be explained by the independent variable. Besides that, the Durbin-Watson is a statistical test which used to examine the auto-correlation from the regression analysis. The Durbin-Watson statistic has a range of value from 1-3. The Durbin-Watson is 1.610 which inside the range. This indicates that there is no inter-item correlation.

\section{Conclusion and Recommendation}

As conclusion, the overall summaries, limitation, implication, and recommendation are discussed in this chapter. The result of this study will be useful for the next research. As well as this may help organization to understand the consumers brand loyalty on which variable to target to further expand their horizon, improving the company reputation, and maximizing the shareholder profits and stakeholder preferences. This will be the recommendation for the future research, which recommend that the next research should focus on a different region of Selangor or expand the data collection are that not involves in this study and for both urban and rural consumers. Also, it's recommended to avoid the usage of convenience sampling method since this method only could retrieve the data from respondents whom are convenient at the particular moment. The recommendation for organization, it is recommended that organizations focuses on stimulating consumer's perception based on consumer behavior and consumer satisfaction. Besides that, recommended that organization to launch more different designs and styles, especially from the fashion runways. In order to keep in touch with consumers and promote in-depth brand loyalty schemes to keep and retain consumers from moving to a different apparel brands. Lastly, the consumers nowadays are much more computer literate. Thus, for the organization should promote the products and information via the Internet to the capture their attention and as a lure to bait.

\section{References}

Achelis, S. B. (2015). Correlation Analysis. Retrieved April 10, 2016, from http://www.metastock.com/customer/resources/taaz/?c=3\&p=44

Allison, P. D. (2002). Missing data: quantitative applications in the social sciences. Sage Publications. https://doi.org/10.1348/000711002159653/full

Arnold, J. (1991). Work Psychology: Understanding human behavior in the workplace. London: Pitman,

Brakus, J. J. (2009). Brand experience: What is it? Who is it measure? Does it affect loyalty? Journal of Marketing, 52-68. https://doi.org/10.1509/jmkg.73.3.52? code=amma-site

Brush, T., Dangol, R., \& O'Brien, J. (2012). Customer capabilities, switching costs, and bank performance. Strategic Management Journal, 1499-1515. https://doi.org/10.1002/smj.1990/full

Čiarnienè, R., \& Vienažindienė, M. (2014). Agility and Responsiveness Managing Fashion Supply Chain. Procedia - Social and Behavioral Sciences, 1012-1019.

Cohen, L., Manion, L., \& Morrison, K. (2013). Research methods in education. New York.

Dahl, D. (2013). Social Influence and Consumer Behavior. Journal of Consumer Research.

Delcourt, C., Gremler, D. D., Riel, A. C., \& Birgelen, M. v. (2013). Effects of perceived employee emotional competence on customer satisfaction and loyalty: The mediating role of rapport. Journal of Service Management, 5-24. https://doi.org/10.1108/09564231311304161

Education, I. F. (2015). What does Cronbach's aplha mean? Institute for Digital Research and Education. Retrieved March 28, 2016, from http://www.ats.ucla.edu/stat/spss/faq/alpha.html

Esmaeilpour, F. (2015). The role of functional and symbolic brand associations on brand loyalty: A study on luxury brands. Journal of Fashion Marketing and Management: An International Journal, 19(4), 467-484. https://doi.org/10.1108/JFMM-02-2015-0011

Fornerino, M., \& D'Hauteville, F. (2010). How good does it taste? Is it the product or the brand? A contribution to brand equity evaluation. Journal of Product \& Brand Management, 34-43, https://doi.org/10.1108/10610421011018374

Fountain, J., \& Lamb, C. (2011). Generation Y as young wine consumers in New Zealand: how do they differ from Generation X? International Journal of Wine Business Research, 23(2), 107-124. https://doi.org/10.1108/17511061111142981

Gilbert, E., \& Chodzaza, H. S. (2013). Service quality, customer satisfaction and loyalty among industrial customers of public electricity utility in Malawi. International Journal of Energy Sector Management, 269-282. https://doi.org/10.1108/IJESM-02-2013-0003 
Gurău, C. (2012). A life-stage analysis of consumer loyalty profile: comparing Generation X and Millennial consumers. Journal of Consumer Marketing, 103-113. https://doi.org/10.1108/07363761211206357

Haj-Salem, N. (2014). The double-edged sword: the postive and negative effects of switchng costs on customer exit and revenge. Journal of Business Research, 1106-1113.

Hill, J., \& Lee, H. H. (2012). Young Generation Y consumers' perceptions of sustainability in the apparel industry. Journal of Fashion Marketing and Management: An International Journal, 16(4), 477-491.

John, J. (2011). An analysis on the customer loyalty in telecom sector in India. African Journal of Marketing Management, 3(1), 1-5.

John, W. (2014). Encyclopedia of Business Analytics and Optimization. IGI Global.

Kim, H. (2012). The dimensionality of fashion-brand experience: Aligning consumer-based brand equity approach. Journal of Fashion Marketing and Management: An International Journal, 16(4), 418-441. https://doi.org/10.1108/13612021211265827

Kursunluoglu, E. (2014). Shopping centre customer service: creating customer satisfaction and loyalty. Marketing Intelligence \& Planning, 32(4), 528-548. https://doi.org/10.1108/MIP-11-2012-0134

Kurt Matzler, A. S. (2015). Switching experience, customer satisfaction, and switching costs in the ICT industry. Journal of Service Management, 117-136. https://doi.org/10.1108/JOSM-04-2014-0101

Leard Statistics. (2013). Multiple Regression Analysis using SPSS Statistics. Retrieved April 11, 2016, from https://statistics.laerd.com/spss-tutorials/multiple-regression-using-spss-statistics.php

Leung, J. W. (2002). Fashion buying criteria of X Generation consumers in Hong Kong. Journal of Fashion Marketing and Management: An International Journal, 63-76. https://doi.org/10.1108/13612020210422473

Liu, F., Li, J., Mizerski, D., \& Soh, H. (2012). Self-congruity, brand attitude, and brand loyalty: a study on luxury brands. European Journal of Marketing, 46(7/8), 922-937. https://doi.org/10.1108/03090561211230098

M.K., W. (2008). Sampling. Retrieved Nov 3, 2015, from http://www.socialresearchmethods.net/kb/sampling.php

Macdonald, B. (2014). 10 tips on fostering consumer loyalty and driving satisfaction. Retrieved from http://www.quirks.com/articles/2014/20140926-2.aspx?searchID=622320783\&sort=5\&pg=1

Matos, C. A., Henrique, J. L., \& Rosa, F. D. (2009). The different roles of switching costs on the satisfaction-loyalty relationship. International Journal of Bank Marketing, 506-523, https://doi.org/10.1108/02652320911002331

Matzler, K., Grabner-Kräuter, S., \& Bidmon, S. (2011). Risk aversion and brand loyalty: the mediating role of brand trust and brand affect. Journal of Product \& Brand Management, 154-162, https://doi.org/10.1108/10610420810875070

McLeod, S. (2015). Independent, Dependent and Extraneous Variables. Retrieved Nov 1, 2015, from http://www.simplypsychology.org/variables.html

Mohammad, E. (2012). Factors Influencing Consumer Behavior in Selecting Mobile Phone Handsets. California US: US International University.

Odindo C, D. J. (2008). Customer Satisfaction, Loyalty and Retention in Financial Services. Nottingham: Financial Services Research.

Oliver, R. L. (1997). Satisfaction: A Behavioral Perspectivetive on the Consumer. New York: McGraw-Hill.

Park, J. N. (1974). A theory of Multidimensional Brand Loyalty. Advances in Consumer Research, 449-459.

Park, J.-G., Park, K., \& Lee, J. (2014). A firm's post-adoption behavior: loyalty or switching costs? Industrial Management \& Data Systems, 114(2), 258-275. https://doi.org/10.1108/IMDS-06-2013-0259

Richard, K. (2011). Consumer Behavior 2011: Millennial Consumers. Loganville: Richard K. Miller and Associates (RKMA).

Schiffman, L., \& Kanuk. (2011). Consumer Behaviour (10th ed.). Pearson.

Schmitt, B. (2013). Consumer Experience and Experiential Marketing: A Critical Review. Book Series: Review of Marketing Research, 25-61. https://doi.org/10.1108/S1548-6435\%282013\%290000010006 
Sekaran, U. (2003). Research Method for Business: A skill building approach (4th ed.). Jon wiley and Sons.

Sidik, S. N. (2014). How Loyal Are You? Factors Influencing Consumer Brand Loyalty.

So, J. T., Parsons, A. G., \& Yap, S.-F. (2013). Corporate branding, emotional attachment and brand loyalty: the case of luxury fashion branding. Journal of Fashion Marketing and Management: An International Journal, 17(4), 403-423.

Solomon. (2006). Consumer Behavior: A European Perspective (3rd ed.). Harlow: Prentice Hall.

Statistics, L. (2013). Linear Regression Analysis in SPSS Statistics - Procedure, assumptions and reporting the output. $\quad$ Retrieved April 14, 2016, from https://statistics.laerd.com/spss-tutorials/linear-regression-using-spss-statistics.php

University of the West of England. (2015). Data Anaysis- Pearson's Correlation Coefficient. Retrieved April 10, 2016, from University of the West of England: http://learntech.uwe.ac.uk/da/Default.aspx?pageid=1442

Valentine, D. B., \& Powers, T. L. (2013). Generation Y values and lifestyle segments. Journal of Consumer Marketing, 30(7), 597-606. https://doi.org/10.1108/JCM-07-2013-0650

Veloutsou, C., Christodoulides, G., \& De Chernatony, L. (2013). A taxonomy of measures for consumer-based brand equity: drawing on the views of managers in Europe. Journal of Product and Brand Management, 238-248, https://doi.org/10.1108/JPBM-02-2013-0256

Williams, P. (2014). Emotions and Consumer Behavior. Journal of Consumer Research, 8-11.

Wu, M. S. S., Chaney, I., Chen, C. H. S., Nguyen, B., \& Melewar, T. (2015). Luxury fashion brands: Factors influencing young female consumers' luxury fashion purchasing in Taiwan. Qualitative Market Research: An International Journal, 18(3), 298-319. https://doi.org/10.1108/QMR-02-2014-0016

Youl, H. (2010). Role of customer orientation in an integrative model of brand loyalty in services. The Service Industries Journal, 1025-1046. https://doi.org/10.1080/02642060802311252

Zarantonello, L., \& Schmitt, B. (2010). Using the brand experience scale to profile consumers and predict consumer behavior. Journal of Brand Management, 532-540.

Zwilling, M. (2013). Customers Remember Experiences, Not Your Brand Logo. Retrieved Nov 1, 2015, from http://www.forbes.com/sites/martinzwilling/2013/08/31/customers-remember-experiences-not-your-brand-1 ogo/

\section{Copyrights}

Copyright for this article is retained by the author(s), with first publication rights granted to the journal.

This is an open-access article distributed under the terms and conditions of the Creative Commons Attribution license (http://creativecommons.org/licenses/by/4.0/). 